\title{
Development of the immature stages of Culex (Culex) saltanensis Dyar (Diptera, Culicidae) under laboratory conditions
}

\author{
João Antonio C. Zequi ${ }^{1} \&$ José Lopes $^{2}$
}

${ }^{1}$ Centro Universitário Filadélfia, Avenida Juscelino Kubitschek, 1626, 86020-000 Londrina-PR, Brasil. biologia@unifil.br
2Departamento de Biologia Animal e Vegetal, Universidade Estadual de Londrina. C. P. 6001, 86051-970 Londrina-PR, Brasil. jea@uel.br

\begin{abstract}
Development of the immature stages of Culex (Culex) saltanensis Dyar (Diptera, Culicidae) under laboratory conditions. Culex (Culex) saltanensis Dyar, 1928 is becoming frequent and abundant in natural and artificial breeding sites in urban and rural areas of Brazil. This study contributes to the knowledge of the biology of a Brazilian strain of $C$. saltanensis. The development of specimens reared individually or grouped was observed. The study was conducted at a constant temperature of $27 \pm 2^{\circ} \mathrm{C}$, 14L:10D photoperiod and $80 \pm 5 \%$ relative humidity. The immature stages were observed every 6 hours until adult emergence, which occurred in 12.29 days among individually reared specimens and in 13.12 days among group-reared specimens. Egg rafts for the experiment were obtained from the laboratory and field. Eggs hatched at a rate of $97.48 \pm 2.32 \%$. More eggs per egg raft were obtained from the field than from the laboratory. Males from individually reared specimens emerged in $12.29 \pm 1.11$ days and females in $13.12 \pm 1.58$ days. The male-female ratio was 1:1. Larval survival rate was higher than $85 \%$ for larvae reared isolated and higher than $95 \%$ for group-reared larvae. The Culex saltanensis life cycle was completed within 12 to 14 days, where larval instars I and IV took the most time to develop and the pupae, the shortest.
\end{abstract}

KEYWORDS. Culex bionomics; eclosion rate; mortality rate; mosquito biology.

\begin{abstract}
RESUMO. Desenvolvimento dos estágios imaturos de Culex (Culex) saltanensis Dyar (Diptera, Culicidae) em condições de laboratório. Culex (Culex) saltanensis Dyar, 1928 está se tornando freqüente e abundante em criadouros naturais e artificiais em áreas urbanas e rurais do Brasil. Este estudo contribui para o conhecimento da biologia de C. saltanensis. Desenvolvimento de espécimes individualizados e agrupados foram observados. O experimento foi conduzido em temperatura constante de $27 \pm 2^{\circ} \mathrm{C}, 14 \mathrm{~L}: 10 \mathrm{E}$ fotoperíodo e $80 \pm 5 \%$ de umidade relativa. Os estágios imaturos foram observados a cada 6 horas até a emergência dos adultos, que ocorreu em 12,29 dias entre os espécimes criados individualmente e em 13,12 dias entre os espécimes criados agrupados. Jangadas de ovos para o experimento foram obtidos a partir de laboratório e de campo. Eclosão dos ovos ocorreu em 97,48 $\pm 2,32 \%$. Mais ovos por jangada foram obtidos a partir do campo do que laboratório. Machos criados individualmente, emergiu em 12,29 $\pm 1,11$ dias e fêmeas em 13,12 $\pm 1,58$ dias. A proporção macho-fêmea foi de 1:1. Taxa de sobrevivência das larvas foi superior a $85 \%$ para larvas criadas isoladas e superior a $95 \%$ para as larvas agrupadas. O ciclo de vida de C. saltanensis foi completado entre 12 a 14 dias, os ínstares I e IV levaram mais tempo para o desenvolvimento, e a pupa foi a fase mais curta.
\end{abstract}

PALAVRAS-CHAVE. Biologia de mosquito; bionomia de Culex; taxa de eclosão; taxa de mortalidade.

Culex (Culex) saltanensis Dyar, 1928 (Diptera, Culicidae) occurs in the Neotropical region and was first recorded in Salta Province, Argentina (type locality). In 1986 and 1988, specimens of this species were also collected in Córdoba Province, Argentina (Almirón \& Brewer 1995). Rossi (1995) registered adults in the Entre Ríos and Corrientes provinces. In Brazil, the species was first recorded in Rio de Janeiro State, where adults were captured from August 1981 to July 1983 (Lourençode-Oliveira 1984). This species was later found in Rio de Janeiro throughout the year and more abundantly in spring and summer (Lourenço-de-Oliveira et al. 1985).

This Culicidae species can colonize human environments, as reported by Lopes (1997a, b), who registered the occurrence of the larva in natural and artificial breeding sites in northern Paraná State, Brazil. The morphometry of eggs and the immature stages of $C$. saltanenis were described by Zequi \& Lopes (2007), and the morphological redescription of the immature stages and the adult were performed by Laurito et al. (2008).
Lourenço-de-Oliveira \& Heyden (1986) collected $C$. saltanensis in Río de Janeiro, from natural and artificial, permanently shallow and sunny ponds with clear or muddy water. Almirón \& Brewer (1996) collected C. saltanensis that had colonized natural habitats and artificial reservoirs in Córdoba Province, Argentina.

Lourenço-de-Oliveira \& Heyden (1986) observed that the species is predominantly ornithophilous, although eclectic when choosing its host. According to Gabaldon et al. (1988), C. saltanensis can become infected with Plasmodium cathemerium, a sparrow homospory. Lourenço-de-Oliveira \& Castro (1991) considers this species the primary vector of P. juxtanucleare in Rio de Janeiro. Sibajev et al. (1993) described a new species of trypanosomatid, Crithidia ricardoi, which is considered the original parasite of $C$. saltanensis.

Biological studies are important for understanding the development, control and dynamics of mosquito species (Service 1993). Considering the scarce information available on C. saltanensis biology, this study concentrated on the biology 
of the immature stages, determining the number of eggs per oviposition, rate of egg eclosion, and duration of larval instar and pupa development of specimens that were reared individually or grouped. The biological differences related to the egg collection sites, field and laboratory, were evaluated.

\section{MATERIAL AND METHODS}

Specimen collection and maintenance of the insectary. The study started when a colony of $C$. saltanensis was stabilized in the laboratory and the adults were reared in $50 \mathrm{x} 40$ x $40 \mathrm{~cm}$ cages with $1 \mathrm{~mm}$ nylon mesh and two short sleeves. Egg rafts were collected from the treatment pond of a soft drink factory in Londrina, Paraná. After stabilization of the adult colony, eggs were collected from the pond every 15 days and added to the immature specimens obtained in the laboratory. The identification of the eggs followed the methods of Zequi \& Lopes (2007). Eggs collected from the field were used for comparisons of oviposition in the field and laboratory.

The experiment was conducted at the Entomology Laboratory of the Department of Animal and Plant Biology at the Universidade Estadual de Londrina.

Procedures and tests. The larvae were reared in $40 \times 28$ $\mathrm{cm}$ trays with a $3.5-\mathrm{cm}$ depth in a BOD MARCONI MA 403 incubator chamber: photoperiod, $14 \mathrm{~L}: 10 \mathrm{D}$; temperature, 27 $\pm 2{ }^{\circ} \mathrm{C}$; and relative humidity, $80 \pm 5 \%$. The temperature was chosen by random observations in the field and after a pilot survival test performed at $20^{\circ} \mathrm{C}, 22^{\circ} \mathrm{C}, 25^{\circ} \mathrm{C}$ and $27^{\circ} \mathrm{C}$. Larvae were fed daily with finely ground particles (approximately $1 \mathrm{~mm}$ ) of puppy dog food. Pupae were transferred to $600-\mathrm{mL}$ polyethylene pots placed inside the cages until the emergence of adults.

Adults were fed on $12 \%$ sugar solution. Females were allowed to feed on a quail, Coturnix japonica, for blood supplementation, three times a week, at dusk. The quail was properly immobilized in a $16 \times 10 \times 6 \mathrm{~cm}$ cage with $1.5 \mathrm{~cm}$ wire mesh. The animals were cared for in accordance with the guidelines of the Brazilian Society for Laboratory Animal Science (Sbcal/Cobea 2002). Egg viability was assessed by analyzing five egg rafts and counting operculated and nonoperculated eggs immediately after egg eclosion.

The reproductive potential of the species was determined by counting the number of eggs per oviposition from each of the 50 rafts obtained in the laboratory and of 50 others obtained in the field. Egg counting was performed using a Zeiss stereomicroscope.

The experiment with the immature stages was started by recording egg eclosion time for 10 rafts obtained in the laboratory; the event was recorded by visual observation for three consecutive days. Next, at least 10 larvae per raft (total of 118 larvae) were mixed and placed in individual cups containing $40 \mathrm{~mL}$ of distilled water, for observation of each individual. At the same time, 600 larvae from 10 rafts were separated into 10 groups and placed in 10 pots (60 larvae each) containing $400 \mathrm{~mL}$ of distilled water.
Isolated larvae were fed daily on $0.01 \mathrm{mg}$ of puppy dog food mill-grounded into $1 \mathrm{~mm}$ particles. For the group-reared larvae, $19.2 \mathrm{mg}$ of the same food was given on alternate days.

Data on larval instar development, mortality, pupation and adult emergence were collected every 6 h over $24 \mathrm{~h}$ for 14 consecutive days. The developmental stages were detected by the exuviae found and then removed from the containers. Larvae were counted once a day for data confirmation.

Adults were classified as males or females according to sexual dimorphism of the antenna. Time of adult emergence was recorded for adults originating from the same raft and reared isolated.

Part of the biological material used in the experiment was deposited in the Museum of Zoology of the Universidade Estadual de Londrina, Paraná, Brazil.

Statistical analysis. Data were analyzed using means, standard deviations, analysis of variance, and Tukey's test at the 5\% level of significance (Spss Inc. 2005).

\section{RESULTS}

The mean number of eggs $(n=50)$ per raft was higher for oviposition in the field (249.14 mean, 131-371 range) than in the laboratory (mean 196.06, range 88-339).

Mean eclosion time for the 10 rafts was at 8:29 am. The event occurred in the incubator chamber $2 \mathrm{~h}$ and $29 \mathrm{~min}$ after light-on. Eclosion may be associated with the beginning of daylight.

The estimated incubation period was 1 day (range 1 to 1.5 days), with observations of oviposition at 6-h intervals. The eclosion rate of $C$. saltanensis eggs per raft in the laboratory was $97.48 \% \pm 2.32$ (mean 225.40 , range 167-310).

The development times of the four larval instars and pupa individually reared are given in Table I. Male and female pupa development times were shorter than the initial larval instars; the fourth-instar was the longest for both males and females. The mean time to complete the life cycle was 12.29 and 13.12 days for males and females, respectively. On average, the male immature stages for those individually reared emerged 0.83 days earlier than females under similar conditions (Table I).

The $C$. saltanensis male-female ratio was close to $1: 1$, as follows: 41-40 for individually reared specimens (Table I) and 270-256 for group-reared specimens.

The development time of group-reared larvae was shorter in I, II and III instars than that of individually reared larvae (Table II). The development time of pupa up to adult was similar for specimens reared grouped and individually. On average, the adults of individually reared specimens emerged 0.77 days earlier than group-reared specimens. The pupal stage of individually reared specimens lasted 1.55 days, compared to 1.21 days for the group-reared specimens (Table II).

No significant differences in total development time were found between specimens of $C$. saltanensis individually and group-reared. The mortality rate of group-reared specimens was not significantly different between larval instars, although 
higher mortality percentages occurred during the larval instar I and the pupa stages (Table III). Among the individually reared specimens, mortality occurred during larval instar I and II and pupa stages (Table III).

Table I. Development time (days) of the four larval instars and pupa individually reared of Culex saltanensis, for males and females, in plastic cups containing $40 \mathrm{~mL}$ of distilled water in laboratory conditions.

\begin{tabular}{cccccc}
\hline \multirow{2}{*}{ Phases } & \multicolumn{3}{c}{ Mean immature duration \pm Standard deviation } & \multirow{2}{*}{ CV\% } \\
\cline { 2 - 5 } & Male & Range & Female & Range & \\
\hline I & $2.93^{*} \pm 0.47 \mathrm{Aa}$ & $1.98-4.43$ & $3.12 \pm 0.58 \mathrm{Ba}$ & $1.73-4.18$ & 9.99 \\
II & $2.12 \pm 0.32 \mathrm{Ba}$ & $2.00-2.32$ & $2.18 \pm 0.45 \mathrm{Ca}$ & $1.71-4.50$ & 6.99 \\
III & $2.25 \pm 0.22 \mathrm{Ba}$ & $1.75-2.50$ & $2.44 \pm 0.37 \mathrm{BCa}$ & $1.94-4.00$ & 5.78 \\
IV & $3.43 \pm 0.32 \mathrm{Aa}$ & $2.75-4.68$ & $3.84 \pm 0.56 \mathrm{Aa}$ & $3.39-5.75$ & 4.59 \\
Pupa & $1.56 \pm 0.12 \mathrm{Ca}$ & $1.35-2.00$ & $1.53 \pm 0.11 \mathrm{Da}$ & $1.36-2.05$ & 1.56 \\
\hline Total & $12.29 \pm 1.11 \mathrm{a}$ & $10.23-14.93$ & $13.12 \pm 1.58 \mathrm{a}$ & $10.91-17.04$ & 5.61 \\
& $(\mathrm{n}=41)$ & & $(\mathrm{n}=40)$ & & \\
CV\% & 6.02 & & 7.32 & & \\
\hline
\end{tabular}

* Primary data

Obs.: Data were transformed into the root of $\mathrm{x}+0$ for the Tukey test

Same capital letters in a column and small letters in the row do not differ according to the Tukey test at $5 \%$ significance level.

Table II. Development time (days) of the four larval instars and pupa individually and grouped reared specimens of Culex saltanensis. SI: specimens individually reared; SG: specimens grouped reared.

\begin{tabular}{|c|c|c|c|c|c|}
\hline \multirow{2}{*}{ Phases } & \multicolumn{4}{|c|}{ Mean duration \pm Standard deviation } & \multirow{2}{*}{$\mathrm{CV} \%$} \\
\hline & SI & Range & SG & Range & \\
\hline I & $3.02 * \pm 0.54 \mathrm{a}$ & $1.73-4.43$ & $2.23 \pm 0.26 \mathrm{~b}$ & $1.73-2.54$ & 6.29 \\
\hline II & $2.15 \pm 0.39 \mathrm{a}$ & $1.71-4.50$ & $1.48 \pm 0.13 b$ & $1.25-1.66$ & 4.74 \\
\hline III & $2.35 \pm 0.32 \mathrm{a}$ & $1.75-4.00$ & $1.71 \pm 0.14 \mathrm{~b}$ & $1.50-1.90$ & 4.47 \\
\hline IV & $3.63 \pm 0.5 \mathrm{~b}$ & $2.75-5.75$ & $6.84 \pm 1.25 \mathrm{a}$ & $4.95-8.88$ & 8.63 \\
\hline Pupa & $1.55 \pm 0.12 \mathrm{a}$ & $1.35-2.05$ & $1.21 \pm 0.51 \mathrm{a}$ & $0.46-2.00$ & 17.42 \\
\hline Total & $\begin{array}{c}12.70 \pm 1.81 \mathrm{a} \\
(\mathrm{n}=81)\end{array}$ & $9.29-20.74$ & $\begin{array}{c}13.47 \pm 1.55 a \\
(\mathrm{n}=526)\end{array}$ & $11.05-16.05$ & 5.47 \\
\hline
\end{tabular}

* Primary data.

Obs. Data were transformed into the root of $\mathrm{x}+0$ for the Tukey test.

Same letters in the row and column do not differ according to the Tukey test at $5 \%$ significance level.

Table III. Death (absolute value and percentage) of the four larval instars and pupa individually and grouped reared specimens of Culex saltanensis in laboratory conditions. SI: specimens individually reared; SG: specimens grouped reared; D: death; M: mortality.

\begin{tabular}{cccccc}
\hline \multirow{2}{*}{ Phases } & \multicolumn{1}{c}{$\mathrm{SI}$} & & $\mathrm{SG}$ \\
\cline { 2 - 3 } \cline { 5 - 6 } & $\mathrm{M}(\mathrm{n}=118)$ & $\mathrm{D}(\%)$ & & $\mathrm{M}(\mathrm{n}=600)$ & $\mathrm{D}(\%)$ \\
\hline I & 15 & $12.71^{*} \mathrm{a}$ & & 21 & $3.5 \mathrm{a}$ \\
II & 9 & $8.74 \mathrm{ab}$ & & 8 & $1.38 \mathrm{a}$ \\
III & 1 & $1.06 \mathrm{~b}$ & & 10 & $1.75 \mathrm{a}$ \\
IV & 1 & $1.08 \mathrm{~b}$ & & 16 & $2.85 \mathrm{a}$ \\
Pupa & 11 & $11.96 \mathrm{a}$ & & 19 & $3.49 \mathrm{a}$ \\
\hline Total & 37 & 31.36 & & 74 & 12.33 \\
CV\% & & 35.78 & & 26.36 \\
\hline
\end{tabular}

* Primary data.

Obs. Data were transformed into the root of $\mathrm{x}+0$ for the Tukey test. Same letters in the row and column do not differ according to the Tukey test at $5 \%$ significance level.
The adult emergence rate was $68.64 \%$ and $87.67 \%$ for individually and group-reared specimens, respectively. At 27 $\pm 2{ }^{\circ} \mathrm{C}$, the adult survival rate of $C$. saltanensis was above $85 \%$ in the life cycle for individually reared specimens, and over $95 \%$ for those group-reared.

\section{DISCUSSION}

The average number of eggs per raft was higher for oviposition in egg batches collected in the field than in the laboratory, probably due to the field variety of hosts. Costa et al. (1994) found 45 to 245 eggs and a mean of 159.59 for $C$. quinquefasciatus fed on quail, a species biologically similar to C. saltanensis (Harbach 2011), whose number of eggs obtained from quail was higher in the laboratory.

Female fertility can be determined by the kind of blood used in blood meals. Grossman \& Lourenço-de-Oliveira (1996) provided human, rooster and frog blood to $C$. saltanensis females and found that the rooster was preferred; they also found that their pre-oviposition period was shorter than that of females fed on human blood. Females fed on rooster laid 20 to 238 eggs per oviposition, and females fed on human blood laid between 3 to 120 eggs (Grossman \& Lourenço-de-Oliveira 1996). These results with rooster are similar to ours, as far as the ornithophily of the species. The hatching rate of $C$. saltanensis larvae in the laboratory was $97.48 \% \pm 2.32$. Camargo et al. (1994) found 93\% for larvae of C. quinquefasciatus Say, 1823, a species that coexists with C. saltanenis in the natural environment (Zequi \& Lopes 2007). Silva et al. (1993/1994) noted that temperature and humidity directly affect the life cycle of Aedes aegypti (Linnaeus, 1762) (Diptera, Culicidae) at 12L:12D. Silva et al. (1993) found that at $25.3^{\circ} \mathrm{C}$ and $65 \%$ humidity, the egg incubation period was on average 5.8 days and the eclosion rate $68 \%$. Increasing temperature to $27^{\circ} \mathrm{C}$ and humidity to $80.5 \%$ resulted in an average incubation period of 2.4 days with hatching rate of $82 \%$.

In the present study, the mean egg stage duration of $C$. saltanensis was shorter with high viability of eggs $(97.48 \%$ hatching). Flexibility to accept different hosts without affecting egg viability can indicate that the species may use several hosts found in nature, including birds, thus supporting the hypothesis of ornithophilous preference, as reported by Grossman \& Lourenço-de-Oliveira (1996).

The larval and pupal stages of several species are shorter for males among populations from the field and laboratory (Clements 1992). Our findings (Table I) corroborate Clements' findings for immature specimens individually reared in the laboratory. Camargo et al. (1994), working with C. quinquefasciatus in the laboratory at $27^{\circ} \mathrm{C}, 80 \%$ humidity and natural photoperiod of approximately 12L:12D, found a mean life cycle duration of nine days for males and 10 for females, similar to that observed in the present study for males and females of $C$. saltanensis (Table I).

Culex development is closely related to temperature, the most appropriate providing lower mortality and loss of fer- 
tility in adults; higher temperatures can decrease the length of the pupal stage and lead to early adult emergence of $C$. saltanensis (Grossman \& Lourenço-de-Oliveira 1996). Random field observations have indicated that a temperature of $27 \pm 2{ }^{\circ} \mathrm{C}$ provides the best artificial environmental condition for the development of this species. In this study, $C$. saltanensis survival rate at $27 \pm 2{ }^{\circ} \mathrm{C}$ in all larval instars was above $85 \%$ in individually reared larvae and over $95 \%$ in group-reared larvae (Table III).

The competition for food among larvae reared in a group could accelerate their development until larval instar III, compared to those individually reared (Table II). Bergo et al. (1990) tested three diets for the development of Anopheles darlingi Root, 1926 (Diptera, Culicidae) and found that all of them affected the development time at the pupal stage: 552,308 or $306 \mathrm{~h}$. Temporary, poor larval nutrition can extend the development time of larval instars or increase mortality during transition to adult (Bergo et al. 1990).

Puppy dog ration was chosen because it is rich in nutrients to supply the needs of Culicidae. No significant differences in total development time were found among larvae of C. saltanensis individually and group-reared. Several laboratory-based studies on $C$. quinquefasciatus, $C$. pipiens Linnaeus, 1758 and $A$. aegypti suggest that these species produce the so-called overcrowding factor that slows growth rate (Service 1993); however, this was not observed in this study.

Nayar \& Sauerman (1970b) also observed that when the larvae of C. nigripalpus Theobald, 1901 were temporarily overcrowded (2000 larvae $/ 500 \mathrm{~mL}$ ), they would split into two large and compact groups. Interestingly, these authors detected the largest numbers of adults from larvae temporarily grouped. Their result can be compared with those obtained in this study for $C$. saltanensis, considering the mortality rate between individually and group-reared larvae (Table III). Nayar \& Sauerman (1970b) also found that a temporary grouping, with or without food, gradually improves the synchronization for pupation peak in grouped larvae of $C$. bahamensis. No statistical difference was detected during the pupal stage of $C$. saltanensis (Table II) between individually and group-reared larvae.

Egg eclosion rate, larval and pupal survival, and adult emergence of $C$. saltanensis at $27 \pm 2^{\circ} \mathrm{C}$ under laboratory conditions were adequate for this species.

\section{ACKNOWLEDGEMENTS}

This work was supported by Capes (Coordenação de Aperfeiçoamento de Pessoal de Nivel Superior) and by the Graduate Program, Universidade Estadual de Londrina (JACZ). Dr. A. Leyva helped us with the translation and editing of the manuscript.

\section{REFERENCES}

Almirón, W. R. \& M. E. Brewer 1996. Classification of immature stage habitats of Culicidae (Diptera) collected in Córdoba, Argentina. Memórias do Instituto Oswaldo Cruz 91: 1-9.
Almirón, W. R. \& M. E. Brewer. 1995. Distribución estacional de Culicidae (Diptera) en áreas periféricas de Córdoba (Argentina). Ecologia Austral 5: 81-86.

Bergo, E. S.; G. M. Buralli; J. L. F. Santos \& S. M. Gurgel. 1990. Avaliação do desenvolvimento larval de Anopheles darlingi criado em laboratório sob diferentes dietas. Revista de Saúde Pública 24: 95-100.

Camargo, M. F.; I. G. Silva \& C. N. Elias. 1994. Ciclo evolutivo do Culex quinquefasciatus (Wiedmann, 1828) (Diptera Culicidae) em condições de laboratório. Revista de Patologia Tropical 23: 191-195.

Clements, A. N. 1992. The biology of mosquitoes. vol. 1, London, Chapman \& Hall, xxiii+509 p.

Costa, P. R. P.; E. E. S. Silveira \& P. B. Júnior-Ribeiro 1994. Influência da temperatura na longevidade e viabilidade do ciclo aquático do Culex quinquefasciatus Say, 1823 (Diptera:Culicidae) em condições de laboratório. Revista Brasileira de Parasitologia Veterinária 3/2: 87-92.

Gabaldon, A.; G. Ulloa \& N. Serpa. 1988. Plasmodium cathermerium, cepa de Icteridae inoculable a palomas, patos y pavos; sus vectores y utilidad en enseñanza e investigación. Boletin de la Dirección de Malariologia y Saneamiento Ambiental 28: 53-68.

Grossman, G. A. \& R. Lourenço-de-Oliveira. 1996. Observações sobre a emergência, longevidade, alimentação sanguínea e oviposição de Culex saltanensis Dyar, em laboratório (Diptera, Culicidae). Revista Brasileira de Entomologia 40: 357-365.

Harbach, R. E. 2011. Classification within the cosmopolitan genus Culex (Diptera: Culicidae): The foundation for molecular systematics and phylogenetic research. Acta Tropica 120: 1-14.

Laurito, M.; A. M. Visintin \& W. R. Álmiron. 2008. Culex saltanensis Morphological Redescription of the Immature and Adult Stages. Journal of the American Mosquito Control Association 24: 203-210.

Lopes, J. 1997a. Ecologia de mosquitos (Diptera: Culicidae) em criadouros naturais e artificiais de área rural no Norte do Paraná, Brasil. VII. Coexistência das espécies. Iheringia Série Zoologia 83: 91-97.

Lopes, J. 1997b. Ecologia de mosquitos (Diptera: Culicidae) em criadouros naturais e artificiais de área rural do Norte do Estado do Paraná, Brasil. VI. Coletas de Larvas no Peridomicílio. Revista Brasileira de Zoologia 14: 571-578.

Lourenço-de-Oliveira R. 1984. Alguns aspectos da ecologia dos mosquitos (Diptera: Culicidae) de uma área de planície (Granjas Calábria), em Jacarepaguá, Rio de Janeiro. I - Freqüência comparativa das espécies em diferentes ambientes e métodos de coleta. Memórias do Instituto Oswaldo Cruz 79: 479-490.

Lourenço-de-Oliveira, R. \& F. A. Castro. 1991. Culex saltanensis Dyar, 1928. Natural vector of Plasmodium juxtanucleare in Rio de Janeiro, Brasil. Memórias do Instituto Oswaldo Cruz 86: 87-94.

Lourenço-de-Oliveira, R. \& R. Heyden. 1986. Alguns aspectos da ecologia dos mosquitos (Diptera: Culicidae), de uma área de planície (Granjas Calábria), em Jacarepaguá, Rio de Janeiro. IV. Preferências alimentares quanto ao hospedeiro e freqüência domiciliar. Memórias do Instituto Oswaldo Cruz 81: 15-27.

Lourenço-de-Oliveira, R.; T. F. Silva \& R. Heyden. 1985. Alguns aspectos da ecologia dos mosquitos (Diptera: Culicidae) de uma área de planície (Granjas Calábria),em Jacarepaguá, Rio de Janeiro. II. Freqüência mensal e no ciclo lunar. Memórias do Instituto Oswaldo Cruz 80: 123-133.

Nayar, J. K. \& D. M. Sauerman Junior. 1970a. A comparative study of growth and development in Florida mosquitoes. Part 1: Effects of environmental factors on ontogenetic timings, endogenous diurnal rhythm and synchrony of pupation and emergence. Journal of Medical Entomology 7: 163-174.

Nayar, J. K. \& D. M. Sauerman Junior. 1970b. A comparative study of growth and development in Florida mosquitoes. Part 2: Effects of larval nurture on adult characteristics at emergence. Journal of Medical Entomology 7: 235-241.

Rossi, G. C. 1995. Culicidios nuevos para las provincias de Entre Ríos y Corrientes. Revista de la Sociedad Entomológica Argentina 54: 97-98.

Sbcal/Cobea. 2002. Principios Éticos para uso de animais de Laboratório. Available at http://cobea.org.br/index.php?pg = Principios Eticos. Accessed $14^{\text {th }}$ May 2010. 
Service, M. W. 1993. Mosquito ecology: field sampling methods. $2^{\text {nd }}$ ed., London, Chapman Hall, xiii+988 p.

Sibajev, A.; R. S. Pacheco; M. J. Soares; E. Cupolillo; A. B. dos Santos \& H. Momen. 1993. Crithidia ricardoi sp. nov. a new species of Trypanosomatidae isolated from Culex saltanensis Dyar, 1928 (Diptera, Culicidae). Memórias do Instituto Oswaldo Cruz 88: 541-545.

Silva, J. G.; F. C. Marlene; E. Miguel \& N. E. Carmeci. 1993. Ciclo evolutivos de Aedes (Stegomyia) aegypti (Linnaeus, 1762) (Diptera, Culicidae). Revista de Patologia Tropical 22: 43-48.
Silva, J. G.; F. C. Marlene; N. E. Carmeci; I. Eliana \& H. S. Adelair. 1993/ 1994. Metodologia de criação de Aedes (Stegomyia) aegypti (Linnaeus, 1762) (Diptera, Culicidae), em condições de laboratório. Revista Goiânia de Medicina 39/40: 23-26.

Spss Inc. 2005. SPSS ${ }^{\circledR}$ for Windows ${ }^{\circledR}$. Version 14.0 [computer program]. SPSS Inc. Chicago.

Zequi, J. A. C. \& J. Lopes. 2007. Morphometry of eggs and immatures of Culex (Culex) saltanensis Dyar (Diptera, Culicidae) obtained in the laboratory and on the field. Revista Brasileira de Zoologia 24: 169-174. 